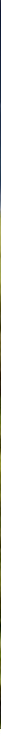

\title{
根から、第二の緑の革命が始まる
}

\section{An underground revolution}

VIRGINIA GEWIN 2010 年 7 月 29 日号 Vol. 466 (552-553)

これまでの農業研究では、根はほとんど無視されてきた。

しかし、環境にダメージを与えずに収量を増やすという目標に向けて、

特に植物育種の分野で、根の重要性が注目され始めている。

根は、地面の下でこんがらがって、泥だ らけになって埋もれているため、研究対 象としてはたいへんなシロモノだ。根を 掘り出すには時間がかかり、時には骨の 折れる作業となる。根の繊細な分岐パ ターンや根毛、さらには根に付着した微 生物を損なわないよう、シャベルで慎重 に掘り進めなければならない。こうした 現実ゆえに、これまでの農業研究では根 はほとんど顧みられず、見過ごされてき た。しかし、多くの科学者が今、生産性 の優れた作物を作り出すカギとして、根 をとらえ始めている。めざすは「緑の革 命」を超えることだ。

1940 年代に始まつたその徹底的な研 究開発の時代には、高収量作物品種の開 発、および農薬、肥料、大量の水の使用 により、急激な食糧増産が進められた。 しかし、その増産によって地下水が枯渴 し、1998 年には窒素肥料使用量が 8 倍 に増加して ${ }^{1}$ 、水系污染などの環境問題
が発生した。収量が飛躍的に増加した一 方で、飢餓に苦しむ人々はなお多数存在 している。そして、土㖶がやせた国々、 灌溉システムが利用できない国々、高価 な肥料が買えない国々など、多くの開発 途上国が緑の革命から取り残された。ペ ンシルベニア州立大学（米国ユニバーシ ティーパーク）の植物栄養学者である Jonathan Lynch は、「こうした過去の 戦略は、現在の増え続ける食糧需要を満 たすのには役立ちません」と話す。

「根こそが、高コストなインプットに 依存しない『第二の緑の革命』のカギを 握っています」と Lynch。根は、植物 が必要とする最も重要な「水」と「栄養素」 を運ぶが、この 2 つ要素は、十分得 られないことが多いのだ。だから根の能 力を高めることができれば、既にそこに あるものが利用でき、それによって「耕 作限界地」を生産性の高い土地に変える こともできるはずだ。そうした可能性が
あるのに、水や肥料を次々に与え続ける 必要があろうはずがない、と Lynch ら は考える。

明らかに、改善の余地がある。植物育 種では、茥ではなく穀粒の生産に多くの エネルギーを投入する矮性品種の開発な ど、「地上」形質の操作によって多大な 進歩が既に達成されている。しかし、根 の形質に関しては、ほとんど手が付けら れていない。「そこに収量を向上させる 可能性が残されているのです。根に仕掛 けられたさまざまな遺伝的変異が見過ご されてきました」と Lynch は話す。こ こでは、根を通じた食糧増産に関する有 望な先進的事例を 4 つ紹介しょう。

\section{特製の根}

根は、その構造が環境に合わせて作られ たときに、最も効率よく働く。深い根は 乾いた土壌の下から水を吸い上げる能力 をもち、また細かな浅い根は、土壌の表 
層にとどまっている限られた栄養素を取 り込むことができる。

オーストラリア連邦科学産業研究機 構（CSIRO；キャンベラ）の植物生物 学者である Michelle Watt は、乾燥し やすい地域に適したコムギ品種の開発に 携わっている。最近のコムギ系統の研究 で、Wattの研究チームは、一部の系統 の根がほかの系統よりも 25 パーセント 深く伸びていくことを発見した ${ }^{2}$ 。研究 チームは、この系統を一般的な栽培品種 と交配して、新しいコムギを400 系統 作り出し、現在インドとオーストラリア で糐場試験を進めている。

Watt は新しい遺伝子ッールも利用し ている。しかし、170 億塩基対のパン コムギゲノムを使っているわけではな い。研究チームが使っているのは、コム ギと同じ亜科に属する温帯性のイネ科植 物で、今年の前半にゲノム配列が解読さ れたミナトカモジグサ (Brachypodium distachyon）のゲノムだ。この小さなゲ ノム（2 億 7100 万塩基対）を用いて、 深い根と関係する遺伝子マーカーを探索 しているのだ。そうしたマーカーを利用 できれば、種から育てた植物を掘り出し て根の長さを測るといったたいへんな作 業をせずに、どのコムギ品種の根が深く まで伸びそうか、種子の段階で明らかに できるのではないかと期待している。

ペンシルベニア州立大学では、Lynch が興味深い形質を発見している ${ }^{3}$ 。根の 組織に細胞間の通気空障を大量に作るト ウモロコシ系統が、その能力をもたない 系統と比べて、水の少ない場合に 8 倍 の収量をあげるのだ。ストレスが加わる と、根に取り込む空気の量を増やすこと で、新たな根の組織を作る代謝コストを 抑え、浮かせたエネルギーを穀粒の成長 に回すのではないか、と Lynch は語る。 この形質が今後の育種研究にどれだけ役 立つのかについては、Lynch にはまだ 確信がない。

Lynch によれば、根の構造に関する 研究はまだ始まったばかりだという。 「いってみれば、今は個々の文字を分析
しているような段階で、ここから始めて、 いずれはシェイクスピア演劇の内容まで 予測したいわけです。予測できない根の 構造から新しい特性が現れてくることも あるはずです」。

\section{目に見えない掃除屋}

根は栄養素を探す。そこで、それを助け る方法を探している研究者もいる。具体 的には、土壌から栄養素を遊離させたり、 毒素を中和したりする能力を高めようと いうのだ。

ブラジル中央部の「セラード」とよば れる草原では、大部分の土壤の酸性度が 高いため、アルミニウムが水に溶けて植 物の根に害を及ぼす。ところが一部の作 物品種は、その害から身を守ることがで きる。根の先から放出する有機酸がアル ミニウムイオンを化学的に不活性化する からだ。

2007 年、コーネル大学 (米国ニュー ヨーク州イサカ）の植物遺伝学者である Leon Kochian の研究チームは、セラー ドのモロコシ品種について、アルミニウ ム耐性のものとアルミニウム感受性のも のとを比較して、アルミニウム耐性をも たらす遺伝子を見つけたと発表した ${ }^{4}$ 。 研究チームは現在、さらに優れた変異体 や別のアルミニウム耐性遺伝子を求めて おり、モロコシや他の作物の地域品種を 選別できるような遺伝子マーカーの探索 を進めている。Kochian によれば、ブ ラジルでの最初の野外研究では、アルミ ニウム耐性をもたらす遺伝的変異を備え た系統は、酸性土袞で生育させた場合、 ほかの品種よりも収量が約 3 分の 1 高 かったという。

アデレード大学 (オーストラリア) の 植物生物学者である Trevor Garnett は、 農業バイオテクノロジー企業のアルカ ディア・バイオサイエンシーズ社（米国 カリフォルニア州デービス）と共同で、 根による土壌からの窒素取り込み効率を 高める方法を実用化しょうとしている。 それは、窒素を含むアミノ酸「アラニ ン」の合成に関与する遺伝子の過剩発現 
を利用する方法だ。Garnett は、「現在は、 肥料として投入した窒素の $40 〜 50$ パー セントしか植物体には取り込まれていま せん。これはとんでもないことです」と 話す。利用されなかった窒素は、むだに なるばかりでなく、湖沼や河川を污染す るからだ。「環境に流出してしまう前に 窒素をすばやく取り込んで保存し、後々 の成長で必要になったときに利用するよ うな、領欲な植物が欲しいですね」と Garnett は語る。

\section{微生物の操作}

別の研究チームは、根圏（根を取り巻く 狭い範囲の土㙵）で増殖する微生物を利 用して、作物収量を高めようとしている。 ただし、まだ初期段階でしかない。例え ば、カビと戦う新たな遺伝子を微生物に 導入したり、新たな微生物を正体不明の 微生物群集に投入したりすることが実行 可能なのかどうか、まだ明らかになって いない。

ローザンヌ大学 (スイス) の生態学者 であるIan Sanders は、ある有望な方 法を最近発見した。Sanders の研究材料 である Glomus intraradices は、一般に 植物から炭素をもらって植物にリン酸な どの無機栄養素を供給している相利共 生菌だ。2010 年 6 月、Sanders は、G. intraradices 個体の交配で新たな核の組 み合わせをもつ子孫が出現し、その一部 を温室育ちのイネに与えるとイネの生育 が 5 倍になることを明らかにした ${ }^{5}$ 。現 在、なぜそうなるのか調べている最中だ。 Sanders は、この技術がリン欠乏土壤で の収量維持に役立つのではないかと考元 ている。

微生物の中には、抑えなければいけ ないものもいる。ワシントン州立大学 (米国プルマン) の植物育種学者 Kim Kidwell は、Rhizoctonia というカビが 原因の根腐れ病に抵抗性をもつ植物を探 索している。彼はエチルメタンスルホ ネートという物質を使ってコムギの変異 体を作り出した。変異体 50 万個から選 別することにより、根腐孔病に非常に高

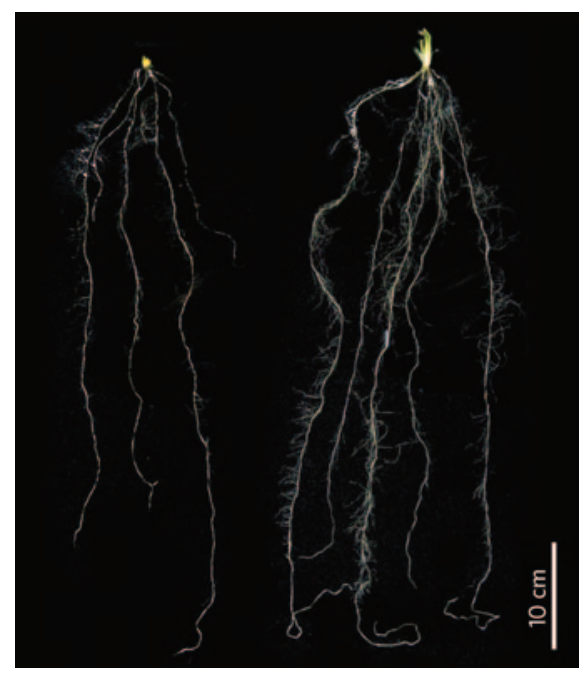

根の成長が盛んなコムギ系統 (右)を使って、 高収量性の試験が行われている。

い耐性をもつ系統が発見された。「前途 は洋々です」と Kidwell は語るが、研 究チームは、その原因遺伝子の同定に手 間取っている。また、それが子孫に受け 継がれていることを確認する遺伝子マー カーがなければ、その形質をもつ植物体 を大規模に選別するのは難しい。さらに、 根腐れ抵抗性遺伝子は、たとえ見つかつ たとしても、野外の条件で同じような結 果を生み出すかどうか、確信はもてない という。「環境の役割は非常に大きいの で、野外で必ずその形質が現れるとは限 らないのです」と Kidwell はいう。

\section{窒素の固定}

コムギやトウモロコシ、イネなどの穀類 の遺伝子を組み換えて自前で窒素を供給 させようという考元方は、何十年も失敗 し続けているにもかかわらず、今後も消 え去ることはないだろう。窒素を土壤か ら吸収する代わりに、大気中から「固 定」できるようになれば、環境を破壊す る高価な肥料は、減少または消滅するだ ろう。しかし、その能力を始めからもつ ているレンズマメやダイズのようなマメ 科植物を模倣するには、Rhizobium など の窒素固定微生物との複雑な共生的相互 作用を植物体内に構築する必要がある。 そのため、多くの研究は、植物に根粒 (Rhizobium が棲む根の無酸素的なこぶ)
を形成させることに集中してきた。

1990 年代前半、根粒形成因子 Nod の 同定が次々に発表された。この Nod はシ グナル伝達分子であり、微生物がこれを 土堙中に出して、マメ科植物に根粒形成 を開始させている。この Nod 因子の受容 体をほかの作物に導入する取り組みは、 これまでのところうまくいっていない。 新しい知見として、ある種の窒素固定共 生細菌Bradyrhizobium が nod 遺伝子を もっていないことがわかり、窒素固定遺 伝子がほかにも存在することが示されて いる。ノッティンガム大学 (英国) の植 物生理学者で、作物窒素固定センターの 所長を務める Edward Cocking は、「も はや根粒形成はそれほど重要ではなく、 ただ植物細胞内に窒素固定細菌を定着さ せることのほうが、大事なのです」と話す。

何らかの窒素固定遺伝子を非マメ科植 物に導入することが、農業科学の重大目 標の 1 つだと考元る研究者は多い。フロ リダ大学（米国ゲインズビル）で微生物 学・細胞科学科長を務める Eric Triplett は、「10 年以上かかることになる研究に 取り組む勇気と資源をもつたチーム」が 必要だろうと話す。

スコットランド作物研究所 (英国ダン ディー）を率いる Peter Gregory は、「こ れまで 40 年間の研究では、根は全く顧 みられませんでした。しかし、非効率的 な栄養素の投入によって経済的・環境的 な帰結がどうなるのか、もはや明らかで す。そうした損害を回避できる唯一の方 法が、根をもつとよく知ることなのです」 と話している。

(翻訳：小林盛方)

Virginia Gewin は、米国オレゴン州ポートランドに 拠点を置くフリーランスのライター。

1. Tilman, D., Cassman, K. G., Matson, P. A., Naylor, R. \& Polasky, S. Nature 418, 671-677 (2002).

2. Kirkegaard, J. A., Lilley, J. M., Howe, G. N. \& Graham, J. M. Aust. J. Agric. Res. 58, 303-315 (2007).

3. Zhu J., Brown, K. M. \& Lynch, J. P. Plant Cell Environ. 33 740-749 (2009).

4. Magalhaes, J. V. et al. Nature Genet. 39, 1156-1161 (2007).

5. Angelard, C., Colard, A., Niculita-Hirzel, H., Croll, D. \& Sanders, I. R. Curr. Biol. 20, 1216-1221 (2010).

社説 (32 ページ) およびオンライン特集 (www.nature. com/food) もご参照ください。 